\title{
TITLE: COST-EFFECTIVE METHOD FOR PRODUCING SELF SUPPORTED PALLADIUM ALLOY MEMBRANES FOR USE IN EFFICIENT PRODUCTION OF COAL DERIVED HYDROGEN
}

\section{QUARTERLY TECHNICAL PROGRESS REPORT}

\author{
REPORTING PERIOD START DATE: 9/09/03 (PROGRAM START) \\ REPORTING PERIOD END DATE: $\quad$ 01/31/05 \\ PRINCIPLE AUTHOR(S): $\quad$ B. LANNING, J. ARPS \\ DATE REPORT WAS ISSUED: $\quad$ 01/28/05 \\ DOE AWARD NUMBER: $\quad$ DE-FC26-03NT41849 \\ SUBMITTING ORGANIZATION: SOUTHWEST RESEARCH INSTITUTE \\ 6220 CULEBRA ROAD (78238-5166) \\ P.O. BOX 28510 (78228-0510) \\ SAN ANTONIO, TEXAS \\ OTHER TEAM MEMBERS: \\ COLORADO SCHOOL OF MINES \\ IDATECH \\ SUBMIT TO: \\ NETL AAD DOCUMENT CONTROL \\ BLDG. 921 U.S. DEPARTMENT OF ENERGY \\ NATIONAL ENERGY TECHNOLOGY LABORATORY \\ P.O. BOX 10940 \\ PITTSBURGH, PA 15236-0940
}

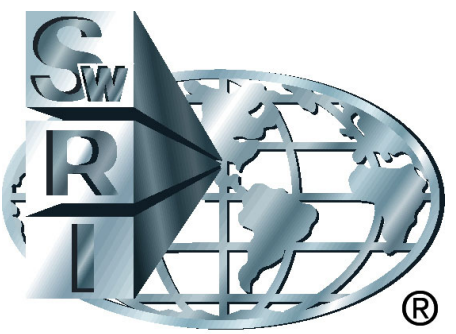

SOUTHWEST RESEARCH INSTITUTE ${ }^{\circledR}$ 


\title{
TITLE: COST-EFFECTIVE METHOD FOR PRODUCING SELF SUPPORTED PALLADIUM ALLOY MEMBRANES FOR USE IN EFFICIENT PRODUCTION OF COAL DERIVED HYDROGEN
}

\section{QUARTERLY TECHNICAL PROGRESS REPORT}

\author{
REPORTING PERIOD START DATE: 9/09/03 (PROGRAM START) \\ REPORTING PERIOD END DATE: $\quad$ 01/31/05 \\ PRINCIPLE AUTHOR(S): $\quad$ B. LANNING, J. ARPS \\ DATE REPORT WAS ISSUED: $\quad$ 01/28/05 \\ DOE AWARD NUMBER: DE-FC26-03NT41849 \\ SUBMITTING ORGANIZATION: $\quad$ SOUTHWEST RESEARCH INSTITUTE \\ 6220 CULEBRA ROAD (78238-5166) \\ P.O. BOX 28510 (78228-0510) \\ SAN ANTONIO, TEXAS \\ OTHER TEAM MEMBERS: $\quad$ COLORADO SCHOOL OF MINES \\ IDATECH \\ SUBMIT TO: \\ NETL AAD DOCUMENT CONTROL \\ BLDG. 921 U.S. DEPARTMENT OF ENERGY \\ NATIONAL ENERGY TECHNOLOGY LABORATORY \\ P.O. BOX 10940 \\ PITTSBURGH, PA 15236-0940
}

APPROVED:

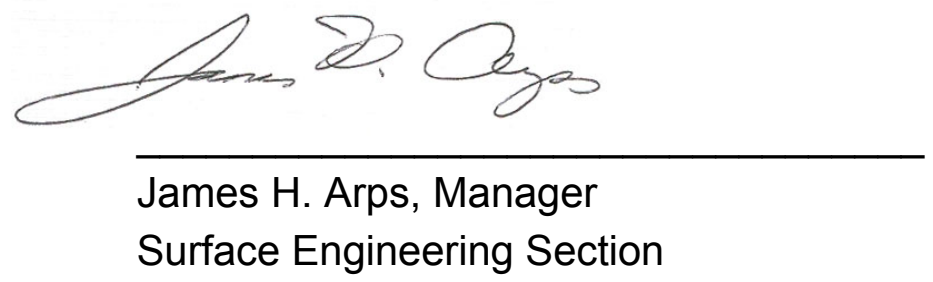




\section{DISCLAIMER}

"This report was prepared as an account of work sponsored by an agency of the United States Government. Neither the United States Government nor any agency thereof, nor any of their employees, makes any warranty, express or implied, or assumes any legal liability or responsibility for the accuracy, completeness, or usefulness or any information, apparatus, product, or process disclose, or represents that its use would not infringe privately owned rights. Reference herein to any specific commercial product, process, or service by trade name, trademark, manufacturer, or otherwise does not necessarily constitute or imply its endorsement, recommendation, or favoring by the United States Government or any agency thereof. The views and opinions of authors expressed herein do not necessarily state or reflect those of the United States Government or any agency thereof." 


\section{ABSTRACT}

Over the last quarter, we developed procedures for producing free-standing, defect free films using rigid silicon and glass substrates over areas up to 12 square inches. Since formation of contiguous $\mathrm{Pd}-\mathrm{Cu}$ films in the 2-3 $\mu \mathrm{m}$-thick range is ultimately governed by the size of the particle contamination on the supporting substrate surface, we have adopted techniques utilized by the semiconductor industry to reduce and eventually eliminate particle contamination. We have found these techniques to be much more effective on rigid substrates and have made a down select decision on removal methods (a key milestone) based on these results and the performance of membranes fabricated by this technique. The path to fabricating even larger membranes is straightforward and will be demonstrated in the coming months.

Hydrogen permeation tests were also conducted this quarter on as-deposited, Pd-Cu membranes, between 6-14 $\mu \mathrm{m}$-thick. In the case of a $6 \mu \mathrm{m}$-thick film, the pure hydrogen flux at 20 psig and $\sim 260{ }^{\circ} \mathrm{C}$ was $36 \mathrm{~cm}^{3}(\mathrm{STP}) / \mathrm{cm}^{2} \mathrm{~min}$. This flux corresponds to a pure hydrogen permeability of $7.4 \cdot 10^{-5} \mathrm{~cm}^{3} \mathrm{~cm} \mathrm{~cm}^{-2} \mathrm{~s}^{-1} \mathrm{~cm} \mathrm{Hg}^{-1 / 2}$ at $250{ }^{\circ} \mathrm{C}$. This value is within $20 \%$ of the pure hydrogen permeability at $250{ }^{\circ} \mathrm{C}$ reported in the McKinley patent. In the case of a $14 \mu \mathrm{m}$-thick membrane tested at $350{ }^{\circ} \mathrm{C}$, the pure hydrogen flux, measured before initiating a pinhole-size leak, was $2.1 \cdot 10^{-5} \mathrm{~cm}^{3}(\mathrm{STP}) \cdot \mathrm{cm} / \mathrm{cm}^{2} \cdot \mathrm{s}^{\bullet} \mathrm{cm} \mathrm{Hg}{ }^{0.5}$. This value is considerably lower than the expected permeability of $\mathrm{Pd}_{60} \mathrm{Cu}_{40}$ materials at $400{ }^{\circ} \mathrm{C}$.

To date, essentially all of the sputtered deposited $\mathrm{Pd}-\mathrm{Cu}$ thin film membranes have had palladium compositions that were as much as $3 \%$ greater than the ideal 60 weight percent composition (this is a direct consequence of sputtering from a 60/40, $\mathrm{Pd} / \mathrm{Cu}$ alloy target). As the concentration of $\mathrm{Pd}$ is increased beyond the optimum 60\% value, a less desirable two-phase structure forms at the higher temperatures (in this case, above $260-280{ }^{\circ} \mathrm{C}$ ). As we continue development of procedures for producing thinner $\mathrm{Pd}-\mathrm{Cu}$ films next quarter, we will also be optimizing alloy composition and corresponding hydrogen permeation flux as well. 


\section{Table of Contents}

DISCLAIMER

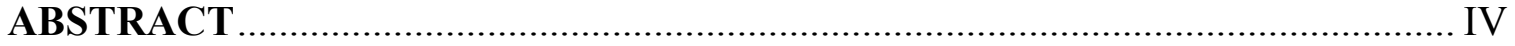

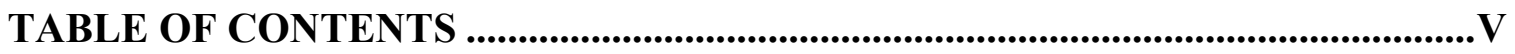

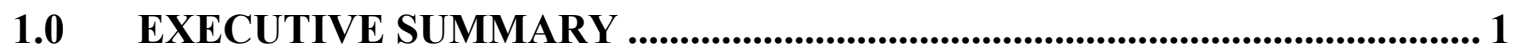

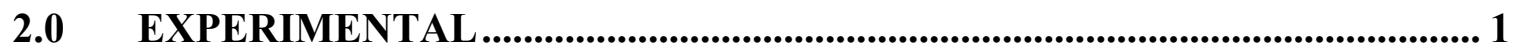

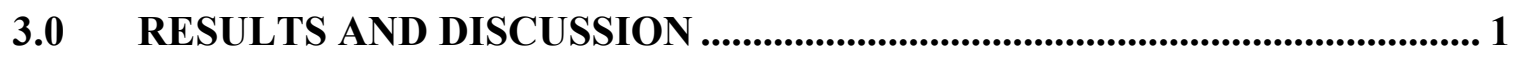

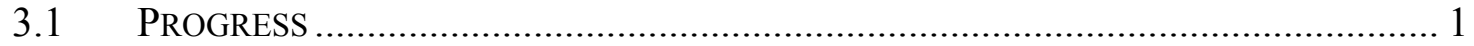

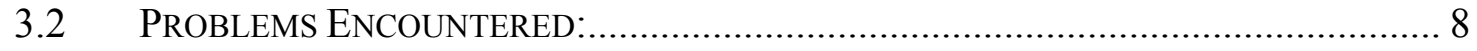

3.3 Plans For NeXt RePorting Period: ......................................................... 8

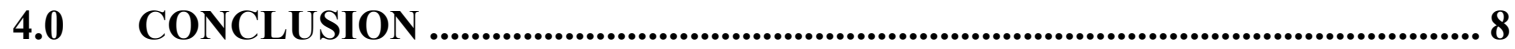

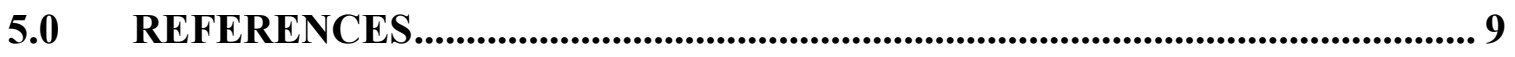




\subsection{EXECUTIVE SUMMARY}

\section{Refer to abstract.}

\subsection{EXPERIMENTAL}

\section{Pd-Cu alloy Vacuum Deposition}

Flexible substrates - As part of a near term effort to reduce through-thickness defects in asdeposited membranes less than $5 \mu \mathrm{m}$, techniques were investigated to modify and optimize the surface properties of the sacrificial polymer backing material(s). Since surface energy (chemical functionalization) and roughness of the polymer surface can have a dramatic effect on the agglomerization and wetting characteristics of a vapor deposited film, two approaches were selected to optimize surface properties of the polymer. First, testing of other polymers such as Kapton (polyimide), and PET were included in addition to PS and PVA (Solublon), to expand the range of polymer surface energies. Next surface pretreatments (modification) with an $\mathrm{Ar} / \mathrm{O} 2$ (95/5) plasma were investigated. Argon creates long-lived carbon radicals while oxygen creates functional groups, such as hydroxyl, carbonyl, or carboxyl that can reduce particulate adhesion and promote uniform deposition.

Both patches and continuous segments (11" wide and up to 48" in length) of the polymer films were treated/coated in the vacuum web coater (controlled drum temperatures between $0-60{ }^{\circ} \mathrm{C}$ ) using either co-evaporation of $\mathrm{Pd}$ and $\mathrm{Cu}$ or magnetron sputtering from a composite target. Plasma treatments were conducted in-line with the $\mathrm{Pd}-\mathrm{Cu}$ deposition steps.

$\underline{\text { Rigid substrates }}$ - Based on procedures reported last quarter (10/30/04), for depositing and releasing Pd-Cu films from rigid silicon substrates, we extended this development to include larger silicon and glass substrates. In brief, processing parameters were optimized to produce films with poor adhesion and minimal electrostatic interaction forces using magnetron sputtering from an alloy target.

$\boldsymbol{H}_{2}$ Testing - A membrane foil is first sandwiched between two circular supports, such as alumina paper, and then sealed with either a Kalrez O-ring (max. use to $315^{\circ} \mathrm{C}$ ) or Grafoil packing material (allowing a $650{ }^{\circ} \mathrm{C}$ upper use temperature in oxygen-free environments) in the $25 \mathrm{~mm}$ Millipore membrane cell. The membrane is then checked with helium to confirm a tight seal and that the membrane is defect (pinhole) free. Subsequently, the membrane is heated to operating temperature to begin permeation testing.

\subsection{RESULTS AND DISCUSSION}

\subsection{Progress}

\subsubsection{Optimization of Pd-Cu Membrane Formation}

\section{Flexible Polymer Substrates}

Although procedures have been developed and routinely employed to deposit and release Pd$\mathrm{Cu}$ films, $2-5 \mu \mathrm{m}$-thick and $>75 \mathrm{in}^{2}$ in area from PS and PVA polymer backing materials, we 
observe appreciable through-thickness defects (pinholes) for film thicknesses less than $6 \mu \mathrm{m}$. Though a small percentage of the defects are related to the deposition process (and therefore potentially eliminated), the majority of defects are due to characteristics of the sacrificial substrate.

In the case of flexible polymer substrates, the low surface energy (related to surface functional groups), roughness, and surface charge (electrostatic) can promote defect formation by methods such as surface particles/contamination, or agglomeration/clustering of incident atoms (as opposed to spreading (wetting) into a contiguous layer). Whether a particle or a cluster on the surface, at some point in the deposition, the incident atoms must bridge across these points to form a contiguous film. Although this "abridged" film is essentially contiguous, the coating will contain "through-thickness" defects (porosity) that compromise the mechanical integrity of the film; i.e., with only minor tensile stress, the reduced cross-section induced at the defect will break and form a pinhole. Hence, to form a $<5 \mu$ m-thick, free-standing, gas impermeable membrane, the characteristics of the substrate must be such that vacuum deposited films must spread at thicknesses $<<1 \mu \mathrm{m}$-thick.

Two treatment methods were investigated to promote spreading of the $\mathrm{Pd}-\mathrm{Cu}$ films on the polymer backing materials; i.e. $\mathrm{Ar} / \mathrm{O}_{2}$ plasma and deposition of a precursor layer, such as $\mathrm{SiO}_{\mathrm{x}}$ with a more favorable surface energy. Although argon plasma treatment (with $5 \% \mathrm{O}_{2}$ ) was shown to decrease water contact angles (increase film wettability) on all plastics tested (PS, PVA, Kapton, and PET), we were not able to completely eliminate defects in films less than $5 \mu \mathrm{m}$. Subsequently, based on results presented in the previous quarter for $\mathrm{SiO}_{2}$ on rigid silicon substrates, an evaporated silica $\left(\mathrm{SiO}_{\mathrm{x}}\right)$ layer was deposited on plasma treated polymer substrates. Unlike the case for rigid silicon substrates, the SiOx-coated polymer substrates did not yield films with a lower defect density. Therefore, irrespective of the surface treatment options tested (plasma or seed layer), we were not able to produce defect-free $\mathrm{Pd}-\mathrm{Cu}$ films on flexible polymer substrates over large areas at thicknesses $<5 \mu \mathrm{m}$ (It is important to note however that defect-free films have been produced at thicknesses $>6 \mu \mathrm{m})$.

\section{Rigid Substrates (silicon/glass)}

Since the primary cause of through-thickness defect formation in thin-films is due to surface particle contamination prior to deposition, we investigated methods, established by the semiconductor industry, to minimize and essentially eliminate effects from particle contamination. We continued using rigid silicon, in addition to including glass, in order to demonstrate the effect of particle contamination on the formation of defects in the films less than $5 \mu \mathrm{m}$-thick. During last quarter, we established vacuum deposition parameters and surface pretreatments of silicon and glass that have enabled us to produce defect-free, $5 \mu \mathrm{m}$ thick Pd-Cu films on 4" diameter silicon and 1" x 3" glass substrates. Two released Pd-Cu films are shown in Figure 1 below. These deposition procedures are currently being further optimized to produce defect-free films $<3 \mu \mathrm{m}$ - thick. Membrane samples on larger area rigid substrates up to $75 \mathrm{in}^{2}$ will also be prepared in the coming months. 


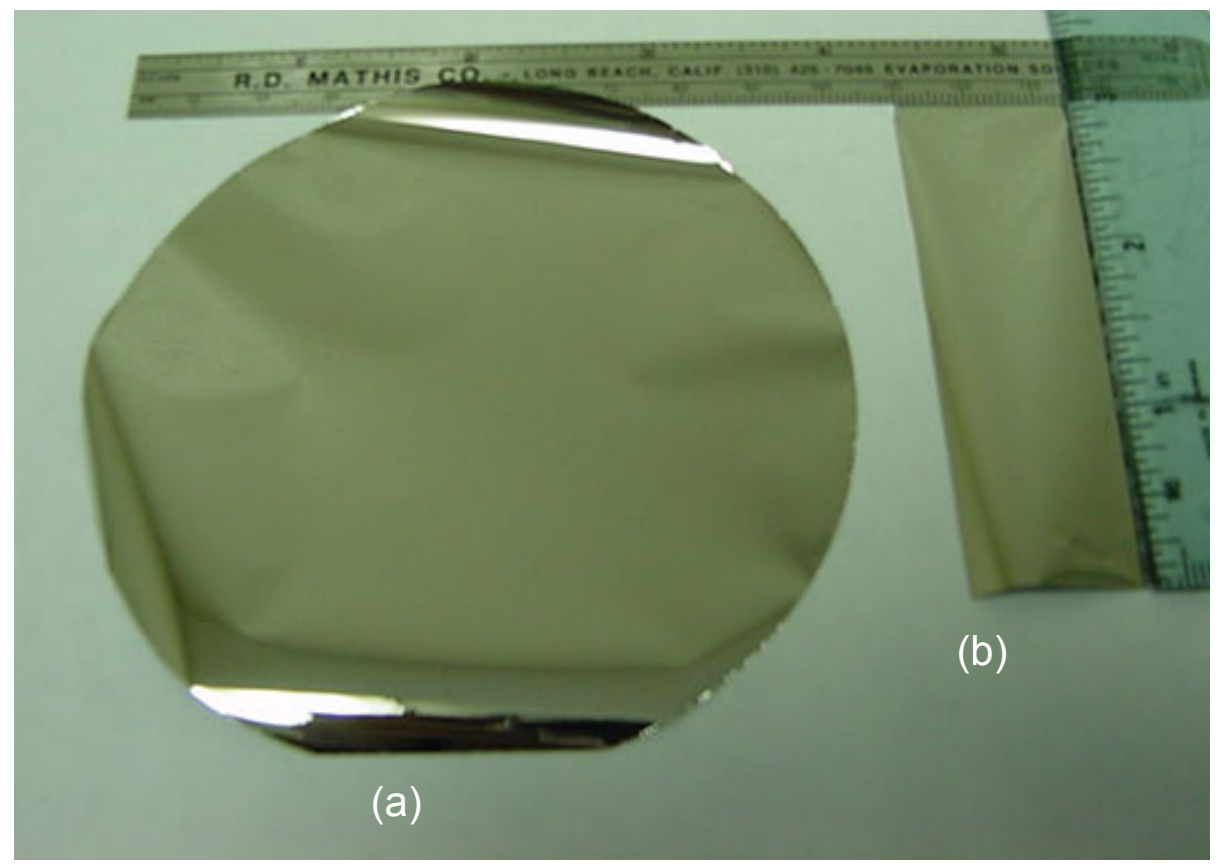

Figure 1 Free-standing Pd-Cu Foils, $5 \mu \mathrm{m}$-thick; a) from rigid, 4" silicon wafer and b) glass slide.

\subsection{2 $\mathrm{H}_{2}$ Permeation Testing}

\section{Results from $\mathrm{H}_{2}$ Permeation Testing (Sputtered films on silicon)}

Permeation testing was completed on 6 and $14 \mu \mathrm{m}$-thick Pd-Cu films. Details from one of each of the two thicknesses are presented below.

Membrane 080304rlp4 (thickness $\sim 6 \mu \mathrm{m}$ ) was sealed in the cell using a Kalrez® o-ring. This membrane exhibited a small helium leak that was attributed to Knudsen diffusion (Pure hydrogen flux vs. driving force measurements showed a pressure dependence of $\Delta \mathrm{P}^{\mathrm{n}}$ where $\mathrm{n}$ was approximately 0.6), indicating that there is likely a pinhole in the membrane. All of the following hydrogen fluxes are corrected for the observed leak. The membrane was heated to $257^{\circ} \mathrm{C}$ under helium, and hydrogen flow to the membrane was initiated after remaining at $257^{\circ} \mathrm{C}$ for 12 hours. The hydrogen flow remained on, and the pure hydrogen flux at $20 \mathrm{psig}$ was measured. The flux at these conditions slowly decreased from about $28 \mathrm{~cm}^{3} / \mathrm{cm}^{2}$ min to about $20 \mathrm{~cm}^{3} / \mathrm{cm}^{2}$ min over a period of 5 days. At this point, the flow to the membrane was switched from hydrogen to helium and left overnight with a feed pressure of 0 psig. After remaining under helium for approximately 15 hours, the membrane was tested again for pure hydrogen permeation at 20 psig. The pure hydrogen flux jumped to $36 \mathrm{~cm}^{3}(\mathrm{STP}) / \mathrm{cm}^{2} \mathrm{~min}$. The pure hydrogen flux was measured again at $36 \mathrm{~cm}^{3} / \mathrm{cm}^{2}$ min the following day after the membrane was exposed to helium again overnight. This flux corresponds to a pure hydrogen permeability of $7.4 \cdot 10^{-5} \mathrm{~cm}^{3} \mathrm{~cm} \mathrm{~cm}^{-2} \mathrm{~s}^{-1} \mathrm{~cm} \mathrm{Hg}^{-1 / 2}$ at $250{ }^{\circ} \mathrm{C}$. This value is within $20 \%$ of the pure hydrogen permeability at $250^{\circ} \mathrm{C}$ reported in the McKinley patent. 
The furnace temperature was then ramped to $275^{\circ} \mathrm{C}$. A temperature of $281{ }^{\circ} \mathrm{C}$ was measured using a thermocouple probe placed inside the cell, on the feed side of the membrane. A continuous flow of pure hydrogen was used on the feed side of the membrane for several days and the pure hydrogen flux at 20 psig decreased steadily to about $14 \mathrm{~cm}^{3} / \mathrm{cm}^{2}$ min over this time period. The temperature was then ramped down again to $257^{\circ} \mathrm{C}$ and the pure hydrogen flux did not recover. It dipped slightly lower to $13 \mathrm{~cm}^{3} / \mathrm{cm}^{2}$ min. Repeating the procedure of leaving the membrane under helium at 0 psig overnight did result in a sharp increase in pure hydrogen flux back to $36 \mathrm{~cm}^{3} / \mathrm{cm}^{2}$ min, which subsequently began to decrease with time.

One hypothesis for the above behavior is that oxygen had been diffusing back through the permeate lines of the system and oxidizing the surface of the foil. To test this hypothesis, the feed side of the membrane was exposed to helium at 20 psig for 15 hours and then hydrogen flux was measured. The pinhole leak ensured that there was helium flow in the permeate lines when the feed side was pressurized to 20 psig. This would limit oxygen from diffusing back through these lines. Figure 2 below shows the behavior of pure hydrogen flux at 20 psig for these conditions.

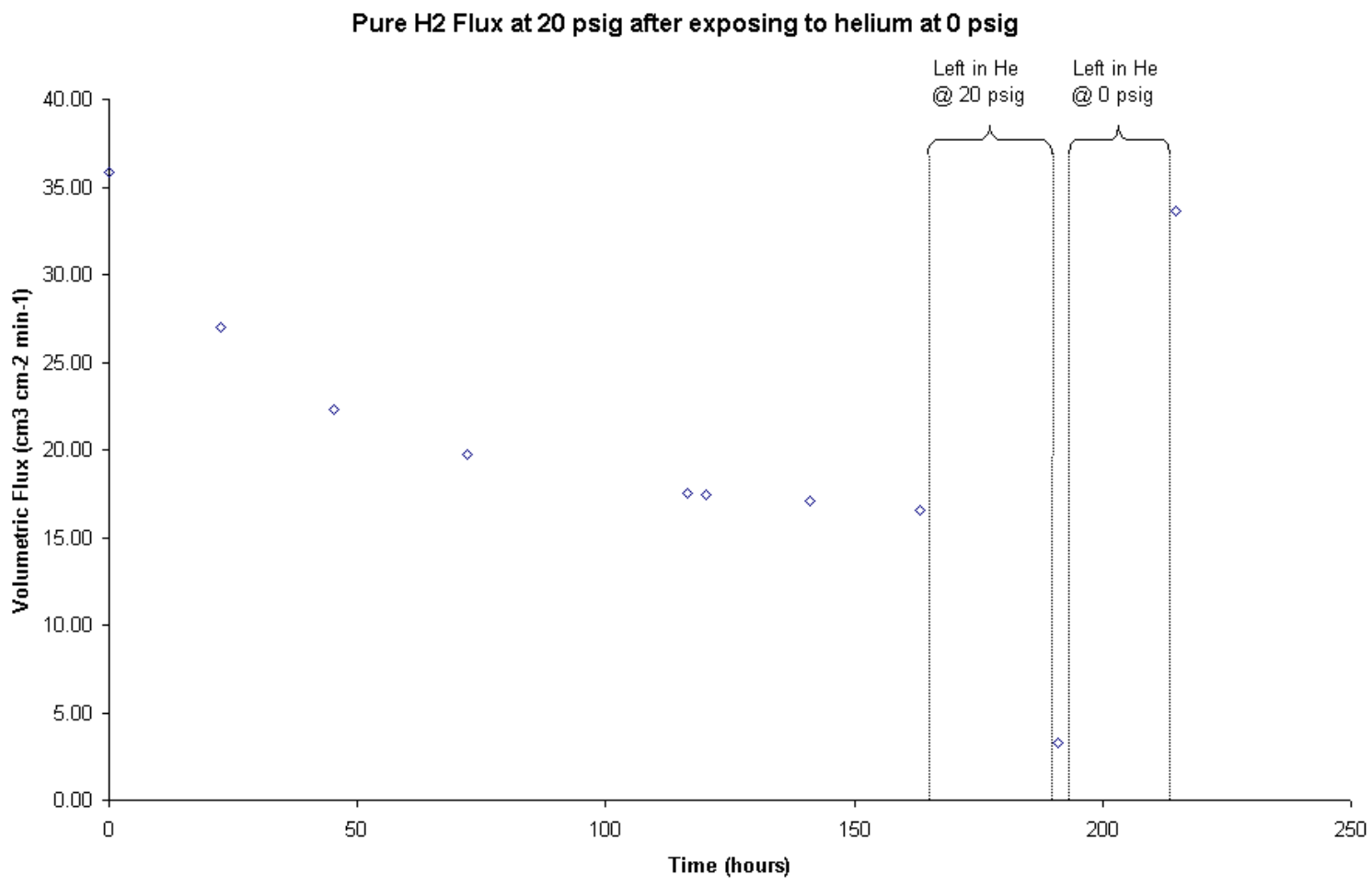

Figure 2. Pure hydrogen flux at $20 \mathrm{psig}$ for membrane $083004 \mathrm{r} 1 \mathrm{p} 4$ at $250{ }^{\circ} \mathrm{C}$. 
The above figure clearly shows the peak in hydrogen flux after exposing the membrane to helium at 0 psig and the decreasing trend from $35.9 \mathrm{~cm}^{3} \mathrm{~cm}^{-2} \mathrm{~min}^{-1}$ to around $16.5 \mathrm{~cm}^{3} \mathrm{~cm}^{-2}$ $\min ^{-1}$, where the flux levels off. The enhanced hydrogen flux was not observed when the membrane was left under helium at $20 \mathrm{psig}$, instead, the flux decreased significantly. This supports our hypothesis that the enhanced hydrogen flux is a result of air oxidation of the foil. The flux recovered back to $33.7 \mathrm{~cm}^{3} \mathrm{~cm}^{-2} \mathrm{~min}^{-1}$ when the membrane was exposed to helium at 0 psig for 15 hours, showing that this effect is reproducible.

Membrane 083104r1p2a (thickness $\sim 14 \mu \mathrm{m}$ ) was placed into the Millipore fixture over a ceramic paper support and sealed using a graphite seal. The ceramic support ensured that there would be no intermetallic diffusion between the foil and the material that makes up the Millipore fixture. Furthermore, the graphite seal gave us the freedom to test at elevated temperatures.

The membrane was leak-free at room temperature and thus deemed acceptable for testing at high temperature. The system was brought to $250{ }^{\circ} \mathrm{C}$ and left under hydrogen. Pure-gas flux measurements were made with a hydrogen feed pressure of $20 \mathrm{psig}$. The hydrogen permeate flow rate showed a gradual decreasing trend from $22.3 \mathrm{~cm}^{3} / \mathrm{min}$ to $11.4 \mathrm{~cm}^{3} / \mathrm{min}$ over a period of 210 hours. The temperature was then raised to $350{ }^{\circ} \mathrm{C}$ to increase the rate at which any sort of phase change could be occurring. From this point on, the pure hydrogen flux began to increase. The system seemed to be approaching a steady state, with a pure hydrogen flux of $4.7 \mathrm{~cm}^{3} / \mathrm{cm}^{2}$ min and then the flux suddenly increased. Tests with helium gas revealed that a pinhole might have formed in the membrane, as there was a measurable helium flux of $0.7 \mathrm{~cm}^{3} / \mathrm{cm}^{2}$ min. Figure 3 shows the behavior of pure hydrogen flow-rate with respect to time at the two temperatures. The pure hydrogen flux measured before the leak corresponds to a hydrogen flux of $2.1 \cdot 10^{-5} \mathrm{~cm}^{3}(\mathrm{STP}) \bullet \mathrm{cm}^{\prime} \mathrm{cm}^{2} \bullet \mathrm{s}^{\bullet} \mathrm{cm} \mathrm{Hg}{ }^{0.5}$. This value is considerably lower than the expected permeability of $\mathrm{Pd}_{60} \mathrm{Cu}_{40}$ materials at $400{ }^{\circ} \mathrm{C}$.

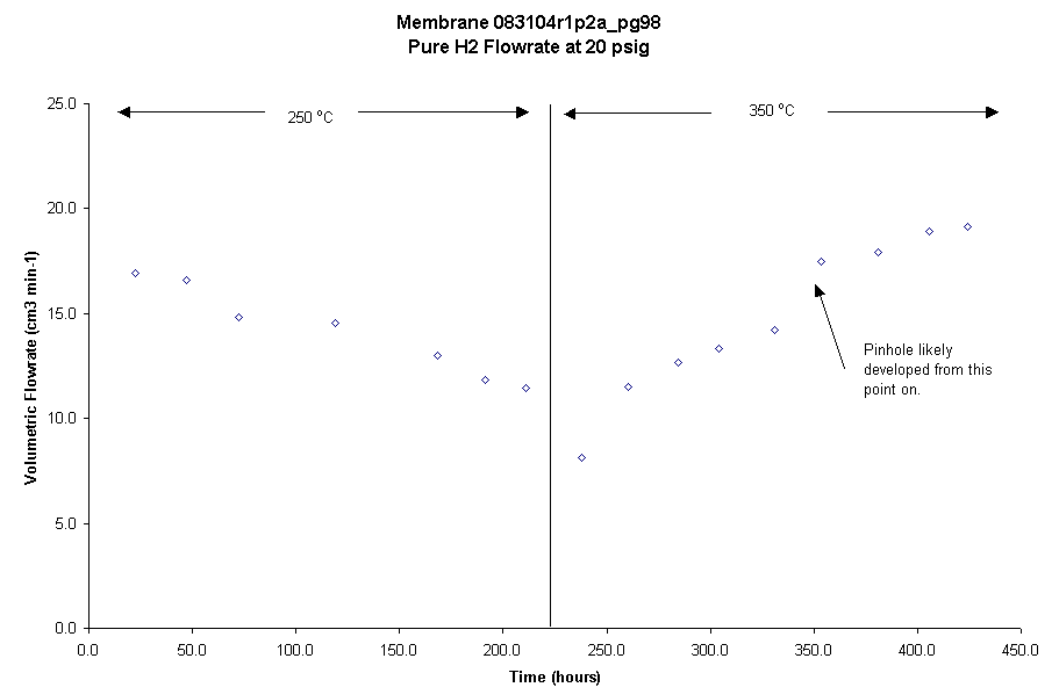

Figure 3. Influence of time on hydrogen permeation of membrane 083104rlp2a with a hydrogen feed pressure of 20 psig. 
A $25 \mu \mathrm{m}$ thick palladium-copper foil known to be $60 \mathrm{wt} . \% \mathrm{Pd}$ was supplied by Idatech and is being used as a standard for compositional analysis of subsequent membranes. A $25 \mathrm{~mm}$ disc of this material was tested for hydrogen permeation. The material was tested as received, with no prior activation. A steady-state measurement of pure hydrogen flux was performed and the hydrogen permeability at $400{ }^{\circ} \mathrm{C}$ was calculated to be $7.2 \cdot 10^{-5} \mathrm{~cm}^{3}(\mathrm{STP}) \cdot \mathrm{cm} / \mathrm{cm}^{2} \bullet \mathrm{s}^{\bullet} \mathrm{cm} \mathrm{Hg} \mathrm{Hg}^{0.5}$. This value is nearly $50 \%$ of the maximum permeability reported in the literature for $\mathrm{Pd}_{60} \mathrm{Cu}_{40}$ materials. Upon examining the foil after testing, it appeared that the surface had significant carbon contamination that may have come from the graphite seal used in the membrane holder. See Figure 4 for an image of the surface of the membrane. This apparent carbon contamination could explain the why the permeability observed is lower than that reported in the literature.

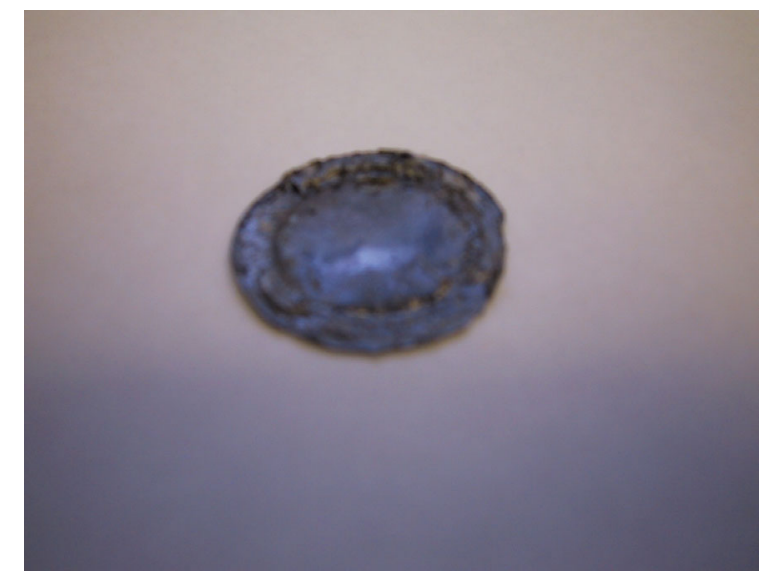

Figure 4. Image of $\mathrm{Pd}_{60} \mathrm{Cu}_{40}$ standard foil showing the apparent carbon contamination on the surface that appeared after testing.

\section{Effect of Membrane foil Pre-treatment (25 $\mu m$-thick foil)}

An experiment was performed to determine the crystal structure of membrane $090104 \mathrm{r} 1 \mathrm{p} 2$. The foil was annealed in nitrogen for 7 days at $450{ }^{\circ} \mathrm{C}$, and then rapidly quenched in an ice bath. The surface of the foil appeared slightly oxidized. Figure 5 shows the XRD pattern of this foil after annealing. This pattern suggests that the crystal structure is fcc and the foil is wholly in the $\alpha$-phase. This is not consistent with the $\mathrm{Pd}-\mathrm{Cu}$ phase diagram for a composition near $60 \mathrm{wt}$ \% $\mathrm{Pd}$. We expected to see peaks corresponding to both the $\alpha$ and $\beta$ phases. EDS analysis of this sample showed a composition of $68 \mathrm{wt} . \% \mathrm{Pd}$, which is more consistent with the observed XRD pattern.

The composition of sample 083004r1p4 was determined, using EDS, to be 63 wt.\% Pd and $37 \mathrm{wt} . \% \mathrm{Cu}$. Table 1 below shows the EDS analysis of this membrane as well as a $60 \mathrm{wt} . \% \mathrm{Pd}$ and 40 wt. \% Cu standard. The results at different spots were averaged and then normalized against the standard. 


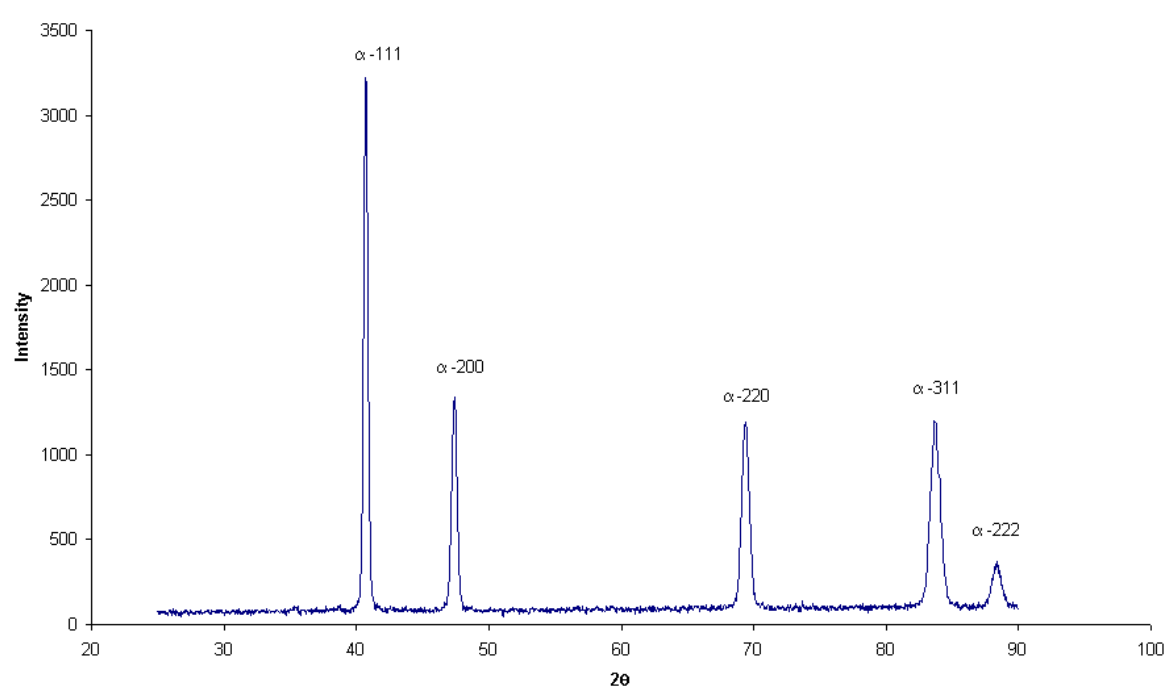

Figure 5. XRD pattern of membrane $090104 \mathrm{r} 2 \mathrm{p} 4$ annealed at $450{ }^{\circ} \mathrm{C}$.

Table 1. EDS analysis of membrane 083004r1p4 and $\mathrm{Pd}_{60} \mathrm{Cu}_{40}$ standard from Idatech.

\begin{tabular}{|c|c|c|c|}
\hline Sample & Spot & Pd wt. \% & Cu wt. \% \\
\hline \multirow{9}{*}{$\begin{array}{l}\mathrm{Pd}_{60} \mathrm{Cu}_{40} \\
\text { Standard }\end{array}$} & 1 & 60.71 & 39.29 \\
\hline & 2 & 60.54 & 39.46 \\
\hline & 3 & 61.97 & 38.03 \\
\hline & 4 & 59.19 & 40.81 \\
\hline & 5 & 59.32 & 40.68 \\
\hline & 6 & 61.60 & 38.40 \\
\hline & 7 & 61.14 & 38.86 \\
\hline & 8 & 59.40 & 40.60 \\
\hline & 9 & 59.37 & 40.63 \\
\hline \multirow{7}{*}{$083004 \mathrm{r} 1 \mathrm{p} 4$} & 1 & 62.45 & 37.45 \\
\hline & 2 & 63.14 & 36.86 \\
\hline & 3 & 65.27 & 34.73 \\
\hline & 4 & 63.33 & 36.67 \\
\hline & 5 & 62.30 & 37.70 \\
\hline & 6 & 63.22 & 36.78 \\
\hline & 7 & 63.57 & 36.43 \\
\hline \multicolumn{2}{|r|}{ Average Pd } & Average $\mathrm{Cu}$ & Total \\
\hline Standard & 60.36 & 39.64 & 100.00 \\
\hline 083004r1p4 & 63.33 & 36.66 & 99.99 \\
\hline \multicolumn{3}{|c|}{ Standardized Standardized } & Total \\
\hline Standard & $\begin{array}{c}P d \\
60.00\end{array}$ & $\begin{array}{c}\mathrm{Cu} \\
40.00\end{array}$ & 100.00 \\
\hline 083004r1p4 & 62.95 & 36.99 & 99.94 \\
\hline
\end{tabular}


The composition determined using EDS is reasonable as it corresponds well to the measured pure hydrogen flux. The steady state, pure hydrogen flux of membrane $083004 \mathrm{r} 1 \mathrm{p} 4$ at $250{ }^{\circ} \mathrm{C}$ was determined to be $3.3 \cdot 10^{-5} \mathrm{~cm}^{3}(\mathrm{STP}) \cdot \mathrm{cm} / \mathrm{cm}^{2} \bullet \mathrm{s}^{\bullet} \mathrm{cm} \mathrm{Hg}^{0.5}$. The McKinley patent (USP $3,439,474)$ reports the pure hydrogen flux at $350{ }^{\circ} \mathrm{C}$ for a membrane that is $62.5 \mathrm{wt} . \% \mathrm{Pd}$ and $37.5 \mathrm{wt} . \% \mathrm{Cu}$ as well as pure hydrogen fluxes for a $60 \mathrm{wt} . \% \mathrm{Pd}$ foil at various temperatures. Using data from the patent and assuming that the activation energy for a $62.5 \mathrm{wt} \% \mathrm{Pd}$ foil is the same as that of a $60 \mathrm{wt} . \%$ foil, we can estimate the flux for the $62.5 \mathrm{wt} . \%$ foil at $250{ }^{\circ} \mathrm{C}$ to be approximately $5.2 \cdot 10^{-5} \mathrm{~cm}^{3}(\mathrm{STP}) \cdot \mathrm{cm}^{-} \mathrm{cm}^{2} \cdot \mathrm{s}^{\bullet} \mathrm{cm} \mathrm{Hg}^{0.5}$. This value compares reasonably well to the hydrogen permeability of membrane 083004 , particularly considering that the composition is even further from the $60 \mathrm{wt} . \% \mathrm{Pd}$ target so a lower permeability is expected.

\subsection{Problems Encountered:}

Although we have established procedures and demonstrated the ability, using these procedures, to produce "free-standing" $\mathrm{Pd}-\mathrm{Cu}$ alloy films over large areas, we have not been able to produce pinhole-free films less than $6 \mu$ m-thick using flexible polymer substrates. With our current efforts to address surface particle contamination and demonstrated ability to produce thinner membranes using flat silicon and glass substrates, we plan to apply these results to larger area rigid substrates as well as a limited series of polymer-type substrates.

\subsection{Plans for Next Reporting Period:}

- Fabrication and permeation testing of "pinhole-free" membranes less than $5 \mu \mathrm{m}$ in thickness,

- Preparation of membranes on rigid substrates up to $75 \mathrm{in}^{2}$ in area,

- Optimization of membrane alloy composition and structure (i.e., effects of single versus two phase structures, optimum $\mathrm{Pd} / \mathrm{Cu}$ ratio, and specific alloy additions),

- Continued efforts to improve methods for handling and sealing membranes less than $5 \mu \mathrm{m}$ in thickness

\subsection{CONCLUSION}

Although efforts were conducted to eliminate pinholes in as-deposited $\mathrm{Pd}-\mathrm{Cu}$ films less than $5 \mu \mathrm{m}$-thick on flexible polymer substrates, employing alternative plastic materials such as Kapton and $\mathrm{PET}, \mathrm{Ar} / \mathrm{O}_{2}$ plasma treatment for increased wettability, and $\mathrm{SiO}_{\mathrm{x}}$ seed layers, we still observed sufficient defects over large areas. In parallel with this effort, however, we developed procedures for producing free-standing, defect free films using rigid silicon and glass substrates and have demonstrated the process to prepare membranes up to 12 square

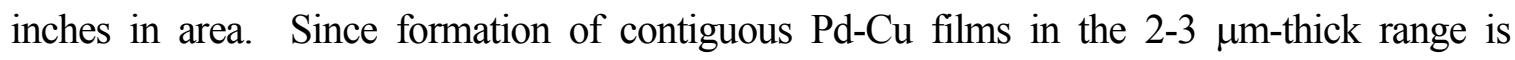
ultimately governed by the size of the particle contamination on the supporting substrate surface, we have adopted techniques utilized by the semiconductor industry to reduce and eventually eliminate particle contamination. A down-select decision has been made to focus our further development on rigid substrates, achieving a stated milestone for the project. 
Hydrogen permeation tests were also conducted this quarter on as-deposited, $\mathrm{Pd}-\mathrm{Cu}$ membranes, between 6-14 $\mu \mathrm{m}$-thick. In the case of a $6 \mu \mathrm{m}$-thick film, the pure hydrogen flux at 20 psig and $\sim 260{ }^{\circ} \mathrm{C}$ was $36 \mathrm{~cm}^{3}(\mathrm{STP}) / \mathrm{cm}^{2}$ min. This flux corresponds to a pure hydrogen permeability of $7.4 \cdot 10^{-5} \mathrm{~cm}^{3} \mathrm{~cm} \mathrm{~cm}^{-2} \mathrm{~s}^{-1} \mathrm{~cm} \mathrm{Hg}^{-1 / 2}$ at $250{ }^{\circ} \mathrm{C}$. This value is within $20 \%$ of the pure hydrogen permeability at $250^{\circ} \mathrm{C}$ reported in the McKinley patent. In the case of a $14 \mu \mathrm{m}$ thick membrane tested at $350{ }^{\circ} \mathrm{C}$, the pure hydrogen flux, measured before initiating a pinholesize leak, was $2.1 \cdot 10^{-5} \mathrm{~cm}^{3}(\mathrm{STP}) \cdot \mathrm{cm}^{\prime} / \mathrm{cm}^{2} \cdot s^{\bullet} \mathrm{cm} \mathrm{Hg}^{0.5}$. This value is considerably lower than the expected permeability of $\mathrm{Pd}_{60} \mathrm{Cu}_{40}$ materials at $400^{\circ} \mathrm{C}$.

To date, essentially all of the vacuum deposited $\mathrm{Pd}-\mathrm{Cu}$ thin film membranes have had palladium compositions that were as much as $3 \%$ greater than the ideal 60 weight percent composition (this is a direct consequence of sputtering from a $60 / 40, \mathrm{Pd} / \mathrm{Cu}$ alloy target). As the concentration of Pd is increased beyond the optimum $60 \%$ value, a less desirable two-phase structure forms at the higher temperatures (in this case, above $260-280^{\circ} \mathrm{C}$ ). As we continue to produce thinner $\mathrm{Pd}-\mathrm{Cu}$ films next quarter, we will also be optimizing the composition and corresponding hydrogen permeation flux as well.

\subsection{REFERENCES}

1. Smithells, Colin J., Smithells Metals Reference book, Eric A. Brandes, Editor,ButterworthHeinemann; 6th Ed, December 1983, London 